\title{
Penggunaan Atrium pada Bangunan Rumah Sakit Bertingkat dan Pengaruhnya terhadap Keselamatan Jiwa terhadap Bahaya Kebakaran
}

\author{
Lily Tambunan'1, Iwan Sudradjat², Suprapto ${ }^{3}$ \\ 1,2 Sekolah Arsitektur, Perencanaan dan Pengembangan Kebijakan, Institut Teknologi Bandung \\ ${ }^{3}$ Puslitbang Perumahan dan Pemukiman, Kementerian PUPR \\ lilyrosalina@yahoo.com
}

\begin{abstract}
ABSTRAK
Penggunaan atrium pada bangunan rumah sakit diyakini dapat mempercepat proses penyembuhan pasien dan mengurangi kesan stres pada bangunan rumah sakit. Namun keberadaan atrium juga dapat menimbulkan bahaya kebakaran karena dapat menjadi sarana penyebaran asap dengan cepat. Penelitian ini bertujuan untuk mengetahui pengaruh keberadaan atrium pada bangunan rumah sakit terhadap tingkat keselamatan jiwa pasien jika terjadi kebakaran. Penelitian dilakukan di dua rumah sakit di Bandung dan Jakarta, Indonesia. Tingkat keselamatan jiwa dinilai melalui perbedaan antara waktu yang dibutuhkan untuk evakuasi, disebut sebagai RSET, dan waktu yang dibutuhkan oleh asap untuk menyebabkan kondisi kritis bagi penghuni, disebut dengan ASET, di mana RSET harus lebih pendek dari ASET. Analisis dilakukan pada dua konfigurasi fisik: atrium terbuka dan atrium tertutup. Hasil studi menunjukkan bahwa dengan atrium terbuka asap dengan cepat menutupi jalur evakuasi sebelum proses evakuasi selesai, atau ASET<RSET. Untuk memenuhi kriteria RSET $<$ ASET, pintu ruang terbakar harus ditutup dan penghalang asap harus dipasang di sekeliling atrium untuk mencegah penyebaran asap ke ruang-ruang pasien.
\end{abstract}

Kata kunci: atrium, kebakaran, rumah sakit, keselamatan jiwa

ABSTRACT

The use of atrium in hospital buildings accelerating the patient's healing process and reduce the impression of stress on hospital buildings. However, the presence of the atrium can also pose a fire hazard because it can be a means of spreading smoke quickly. This study determines the effect of atriums in hospital buildings on the level of life safety in the event of a fire. The study was conducted at two hospitals in Bandung and Jakarta, Indonesia. The level of life safety is assessed through the difference between the time needed for the evacuation, referred to as RSET, and the time taken by smoke to cause a critical condition for occupants, called ASET, where RSET must be shorter than ASET. The analysis carried out on two physical configurations: open and closed atrium, and the results of this study showed that with an open atrium, the smoke quickly covered the evacuation route before the evacuation process completed, or ASET<RSET. The fire room door must be closed, and the smoke-barrier must be installed around the atrium to prevent the spread of smoke into patient rooms, thus fulfill the ASET<RSET criteria.

Keywords: atrium, fire, hospital, life safety

\section{Pendahuluan}

Atrium semakin banyak digunakan pada bangunan-bangunan bertingkat dengan berbagai fungsi baik hunian maupun komersial. Meningkatnya penggunaan atrium dari masa ke masa karena atrium memiliki keuntungan, khususnya dalam tiga aspek, yaitu arsitektural, lingkungan, dan ekonomi. Selain sebagai ruang interaksi sosial atrium memungkinkan lebih banyak ruang-ruang yang mendapatkan cahaya alami dan 
terhubung dengan lingkungan luar bangunan. Dipercaya bahwa adanya akses ke spektrum pencahayaan alami dapat memberikan lingkungan yang lebih sehat dan produktif (Gritch and Eason, 2016). Pada bangunan rumah sakit bertingkat adanya atrium juga dapat menciptakan lingkungan yang tidak menegangkan yang dipercaya dapat mempercepat kesembuhan pasien. Adanya pencahayaan alami siang hari yang berkualiatas pada bangunan rumah sakit dapat memperbaiki kinerja paramedis dan mengurangi jumlah kesalahan dalam pekerjaan (Iyendo and Halil, 2014).

Namun penggunaan atrium juga membawa konsekuensi bagi keselamatan jiwa penghuni ditinjau dari risiko kebakaran. Penelitian membuktikan bahwa atrium dapat menjadi sarana penjalaran asap yang efektif dan cepat pada saat terjadi kebakaran, bahkan kebakaran kecil pada bangunan beratrium pun akan menghasilkan jumlah asap yang sangat besar. Asap akan naik dan mula-mula mengisi bagian teratas atrium, kemudian menyebar secara horisontal melalui bukaan-bukaan ke lantai-lantai lainnya (Butcher, 1979). Asap lebih berbahaya terhadap keselamatan jiwa penghuni dibanding api. Berdasarkan data statistik kebakaran (NFPA, n.d.) dan (USFA-FEMA, 2017), sebagian besar kematian akibat kebakaran bukan disebabkan oleh luka bakar, tetapi oleh asap yang terhirup. Produk beracun dalam asap adalah faktor signifikan dalam melumpuhkan individu karena dengan cepat merusak kemampuan mereka untuk melarikan diri (Miller, 2005). Hasil penelitian juga membuktikan bahwa semakin tinggi tingkat kepadatan asap, semakin pendek jarak pandang (Butcher, 1979). Asap pekat juga dapat menurunkan kemampuan berpikir dan dengan cepat dapat menurunkan ketajaman visual (Jin, 1997), serta menyebabkan penundaan evakuasi, berkurangnya kecepatan bergerak serta bertambahnya waktu evakuasi (Xie et al., 2020; Cote and Bugbee, 1988). Selain menurunnya kecepatan evakuasi, berkurangnya jarak pandang akan meningkatkan jarak tempuh menuju eksit (Jeon et al., 2011).

Tidak seperti bagian lain bangunan yang memiliki lantai, langit-langit, dan dinding yang dapat membentuk kompartemen, atrium tidak memiliki pemisah fisik yang dapat membatasi penyebaran api dan asap secara horizontal dan vertikal. Jika terjadi kebakaran di atrium, maka asap akan naik dan mula-mula mengisi bagian teratas atrium, kemudian menyebar secara horisontal melalui bukaan-bukaan ke lantai-lantai lainnya. Karena tidak ada pemisah fisik maka asap akan menyebar sampai ke bagian bangunan yang jauh dari sumber api. Selain itu, atrium dapat mengandung sejumlah besar bahan mudah terbakar dan menampung banyak penghuni yang dapat terpapar asap pada saat terjadi kebakaran (Butcher, 1979; Gutiérrez-montes and Rein, 2009). Penyebaran asap kebakaran di dalam atrium merupakan sebuah fenomena yang kompleks karena melibatkan banyak faktor yang beragam. Dari sejumlah eksperimen kebakaran pada atrium diketahui bahwa kecepatan dan pola penyebaran asap dipengaruhi oleh beberapa faktor, antara lain ketinggian atrium (Xu et al., 2018), metode pengendalian dan pembuangan asap serta posisi ventilasi (F. Liu, 2001; Qin et al., 2009; Shi et al., 2007), lokasi sumber api (Qin et al., 2009), tingkat pelepasan panas (Gutiérrez-Montes et al., 2008), dan konfigurasi atrium (Doheim et al., 2014). Khusus untuk bangunan rumah sakit, kemungkinan banyak pengunjung lanjut usia atau difabel yang sedang berada di atrium pada saat kejadian kebakaran, di mana mereka membutuhkan waktu lebih lama dan bantuan untuk menyelamatkan diri. Karena itu atrium pada bangunan rumah sakit harus dilengkapi dengan sistem proteksi kebakaran dengan standar yang lebih tinggi daripada bangunan beratrium lainnya dengan fungsi yang berbeda (NHS Department of Health, 2013).

Untuk menghindari risiko bagi keselamatan jiwa terhadap bahaya kebakaran, pada bangunan harus tersedia cukup waktu untuk memindahkan penghuni ke tempat aman sebelum terjadi kondisi berbahaya atau kondisi tak tertahankan (untenable condition) yang disebabkan oleh asap dan panas. Konsep ini kemudian dirumuskan 
menjadi kriteria kinerja keselamatan jiwa terhadap bahaya kebakaran dan dikenal dengan kriteria Required Safe Egress Time (RSET) < Available Safe Egress Time (ASET). Terdapat istilah yang berbeda-beda untuk masing-masing fase waktu RSET (Pauls, 1988; Harada, 1999; Babrauskas, 2010; Yung, 2008), namun secara ringkas komponen RSET dapat dikelompokkan menjadi dua periode waktu, yaitu Waktu Pra-evakuasi dan Waktu Evakuasi. Waktu Pra-evakuasi terdiri dari komponen waktu kebakaran terdeteksi dan waktu respon. Sedangkan Waktu Evakuasi adalah waktu antara dimulainya sampai selesainya evakuasi atau sama dengan waktu tempuh. Faktor-faktor yang berpengaruh terhadap Waktu Pra-evakuasi adalah jenis atau spesifikasi alat deteksi yang digunakan dan tingkat kemampuan penghuni dalam merespon bahaya (Pauls, 1988; D. A. Purser and Bensilum, 2001; Bryan, 2008;Kuligowski, 2008); Fahy, 2008). Kemampuan merespon terkait dengan kemampuan mengenal tanda peringatan, reaktifitas, mobilitas, dan keterbatasan fisik (SFPE-NFPA, 2007). Dengan kata lain karakteristik respon penghuni lebih dipengaruhi oleh aspek sosial dibanding oleh aspek konstruksi bangunan (Pauls, 1988; D. A. Purser and Bensilum, 2001; Bryan, 2008; Gwynne and Boswell, 2009; Kuligowski 2008; Kobes et al., 2010).

Waktu evakuasi merupakan waktu yang dibutuhkan untuk menempuh jalur evakuasi sampai ke tempat yang dianggap aman. Prediksi waktu evakuasi dilakukan untuk menjamin bahwa seluruh penghuni dapat mencapai tempat yang aman sebelum terpapar panas dan produk-produk kebakaran lainnya. Telah banyak studi dilakukan untuk menentukan persyaratan waktu evakuasi yang dibutuhkan (Harada, 1999; Pauls, 1988; Yung, 2008; Fahy, 2008; O’Connor, Daniel J., Cohn, 2008; Lathrop, 2008). Dari hasil studi tersebut disimpulkan bahwa secara umum waktu evakuasi dipengaruhi oleh dua faktor, yaitu kecepatan tempuh (travel speed) dan jarak tempuh (travel distance). Kecepatan tempuh merupakan fungsi dari karakteristik kecepatan dan kepadatan penghuni, di mana karakteristik kecepatan tergantung pada mobilitas, umur, gender, dan kondisi jalur evakuasi (lantai datar atau tangga) yang dilalui. Sementara kepadatan penghuni tergantung pada jumlah penghuni dan luas jalur evakuasi yang dilalui. Selain dua faktor tersebut, waktu evakuasi dipengaruhi pula oleh tingkat kepadatan asap, kondisi sistem deteksi dan pemadam kebakaran serta sistem pengendali asap pada jalur evakuasi selama berlangsungnya proses evakuasi.

Proses evakuasi di rumah sakit lebih rumit dibandingkan dengan bangunan lainnya karena jumlah penghuni dengan mobilitas rendah pada bangunan rumah sakit jumlahnya jauh lebih banyak. Pada umumnya pasien di rumah sakit tidak dapat menyelamatkan diri tanpa bantuan staf. Rasio antara petugas dan pasien kemungkinan tidak mencukupi apalagi jika kebakaran terjadi pada malam hari di mana jumlah staf biasanya lebih sedikit dibanding pada siang hari sehingga proses persiapan pasien membutuhkan waktu lama (Rahouti, Datoussaid, and Lovreglio, 2016). Selain masalah kecukupan staf, faktor-faktor lain yang menjadikan evakuasi kebakaran di rumah sakit tidak praktis dan berpotensi memperpanjang waktu evakuasi adalah masalah kompleksitas konfigurasi bangunan, dan ketika terpaksa dilakukan evakuasi pasien secara vertikal menggunakan tangga. Penggunaan alat bantu evakuasi seperti tempat tidur juga dapat menghambat pergerakan saat memindahkan pasien dan berpotensi menunda evakuasi orang lain (Hunt et al., 2020). Pada bangunan rumah sakit yang memiliki atrium, penundaan evakuasi ini berisiko bagi pasien khususnya yang berada di lantai atas karena kemungkinan asap tiba lebih dahulu sebelum proses evakuasi selesai. Di sisi lain apabila kebakaran melibatkan unit perawatan intensif (ICU), maka evakuasi pasien selain berbahaya bagi keselamatan jiwa pasien, juga sangat sulit dilakukan karena banyaknya peralatan penunjang hidup yang dipasang pada tubuh pasien.

Adanya kecenderungan pemakaian bahan-bahan mudah terbakar pada bangunan rumah sakit modern membuat beban api bertambah. Bahan-bahan mudah terbakar yang 
terdapat pada bangunan rumah sakit meliputi seprei, sarung tangan, pakaian, peralatan diagnostik dan pengobatan, biasanya barang-barang ini disimpan dalam jumlah besar (Belles, 1986; O'Connor, Daniel J., Cohn, 2008). Jenis bahan mudah terbakar yang digunakan pada ruang-ruang pasien seperti kayu dan busa dapat menghasilkan api yang membesar dalam waktu singkat. Lemari kayu yang terbakar menimbulkan bahaya dalam waktu paling lambat 120 detik, sementara pada kebakaran kasur polystyrene api akan memenuhi ruangan dalam waktu 7.5 menit setelah terbakar (Belles, 1986). Cepatnya api membesar dan asap menyebar pada bangunan rumah sakit beratrium dapat menyebabkan ASET lebih pendek dibandingkan RSET. Karena itu penggunaan atrium pada bangunan rumah sakit khususnya pada bangunan rawat inap bertingkat dapat menjadi hal yang kontradiktif. Studi ini ingin mengetahui sejauh mana konsekuensi penggunaan atrium pada bangunan rumah sakit bertingkat terhadap keselamatan jiwa pasien dan bagaimana strategi untuk menghambat kecepatan penyebaran asap dan panas agar tercapai kriteria RSET<ASET.

\section{Bahan dan Metode}

Metode penelitian menggunakan pendekatan berbasis kinerja yaitu tingkat keselamatan diukur berdasarkan keterpenuhan terhadap kriteria RSET<ASET. Ada beberapa definisi yang digunakan untuk membedakan dan membagi komponen waktu RSET (Babrauskas, 2010; Harada, 1999; Pauls, 1988; D. A. Purser and Bensilum, 2001; Yung, 2008), meskipun demikian secara umum komponen RSET dapat dikelompokkan menjadi dua komponen waktu, yaitu Waktu Pra-evakuasi dan Waktu Evakuasi. Waktu Pra-evakuasi adalah lama waktu yang dibutuhkan untuk merespon tanda bahaya yaitu sejak alarm berbunyi sampai persiapan evakuasi selesai dilakukan. Waktu Evakuasi adalah periode antara dimulainya evakuasi sampai pasien tiba di tempat yang aman (Gambar 1).

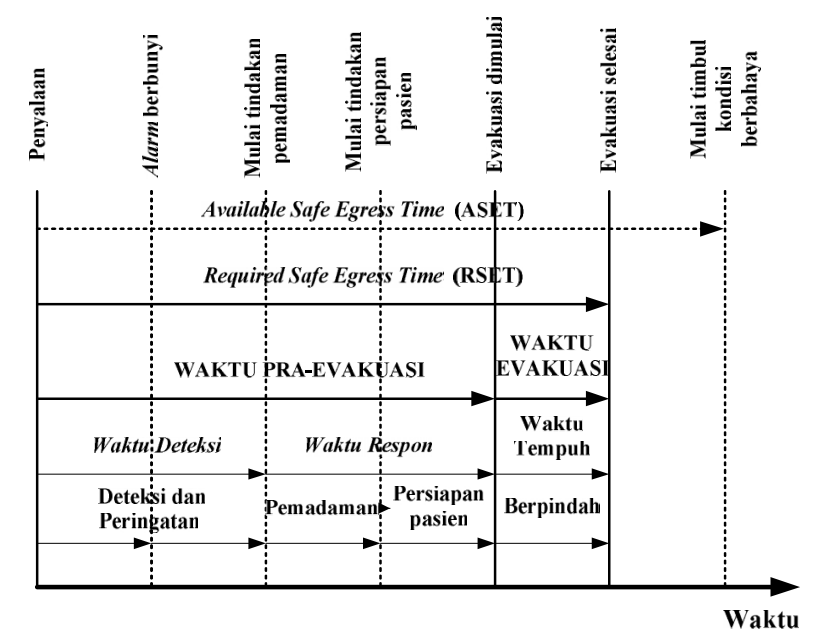

Gambar 1. Komponen RSET

\subsection{Bangunan Kasus Studi}

Obyek studi adalah bangunan rawat inap bertingkat pada dua buah rumah sakit milik Pemerintah di Bandung dan Jakarta, Indonesia (selanjutnya disebut RS1 dan RS2). Bangunan RS1 berlantai empat, luas total bangunan $9.000 \mathrm{~m} 2$, menampung 66 buah kamar tidur. Terdapat dua buah atrium yang menerus dari lantai dasar sampai ke lantai 4 dan tiga buah eksit berupa tangga kebakaran (Gambar 2). Di sekeliling atrium terdapat 
koridor yang sekaligus menjadi jalur evakuasi menuju eksit. Atrium tidak dipisahkan dari koridor di sebelahnya dengan penghalang api dengan tingkat ketahanan api tidak kurang dari 1 jam sebagaimana disyaratkan pada PERMEN PU No.26/PRT/M/2008.

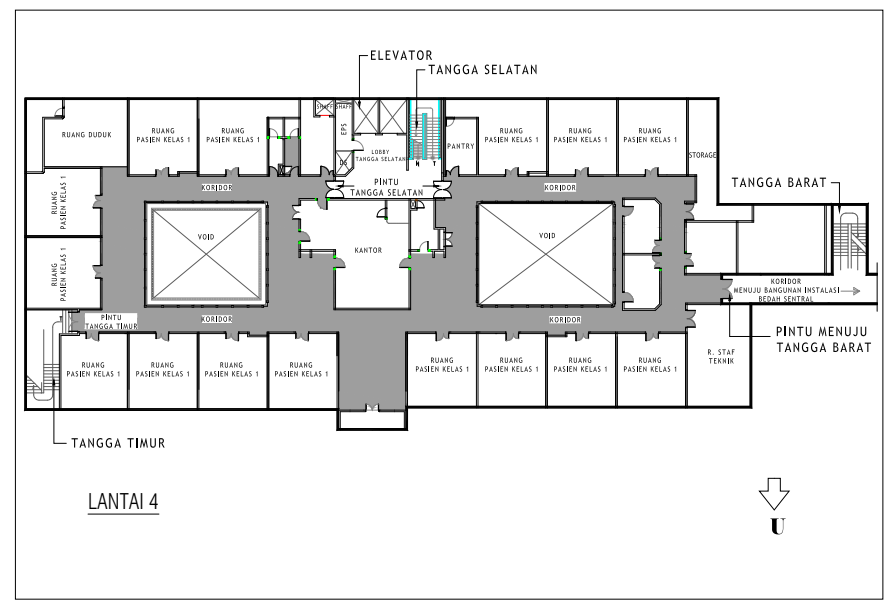

Gambar 2. Denah tipikal bangunan RS1. Tanda silang menunjukkan lokasi atrium dan koridor yang berwarna abu-abu adalah jalur evakuasi

Bangunan rawat inap RS2 berlantai delapan dengan luas 17,664 m2, menampung 143 buah ruang tidur pasien, termasuk ruang-ruang tidur untuk perawatan intensif. Bangunan rawat inap menyatu dengan Gedung Administrasi yang terletak pada sisi Baratnya, dihubungkan dengan koridor dan pintu pada masing-masing lantai. Pada bangunan ini terdapat tiga buah eksit, yaitu tangga kebakaran pada ujung barat dan di tengah bangunan, serta sebuah ramp yang terletak pada ujung timur bangunan (Gambar 3). Di sekeliling atrium terdapat koridor yang sekaligus menjadi jalur evakuasi menuju eksit. Atrium tidak dipisahkan dari koridor di sebelahnya dengan penghalang api dengan tingkat ketahanan api tidak kurang dari 1 jam sebagaimana disyaratkan pada PERMEN PU No.26/PRT/M/2008.

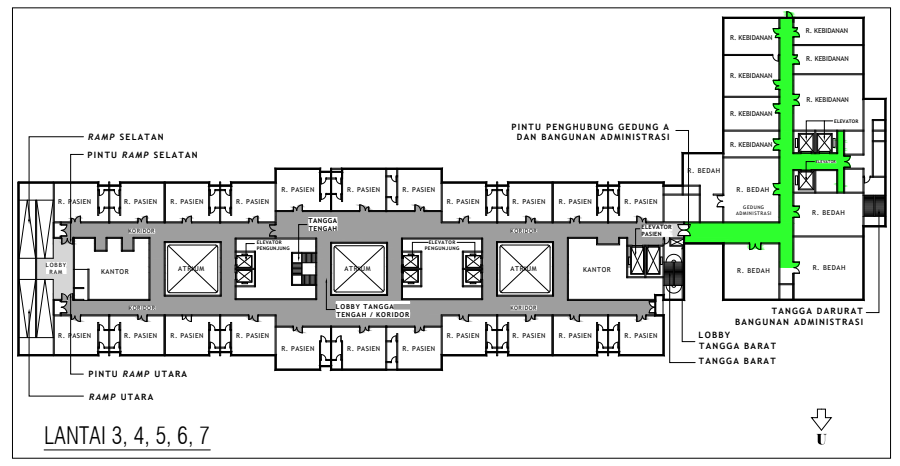

Gambar 3. Denah tipikal bangunan RS2. Tanda silang menunjukkan lokasi atrium. Jalur evakuasi ditunjukkan oleh koridor yang berwarna abu-abu (di dalam bangunan rawat inap) dan berwarna hijau (di dalam bangunan administrasi)

\subsection{Variabel}

Dalam penelitian ini Waktu Pra-evakuasi diukur berdasarkan waktu yang dibutuhkan oleh staf untuk mendeteksi kebakaran, memadamkan api dan menyiapkan pasien sebelum berpindah ke tempat yang aman. Sementara Waktu Evakuasi diukur berdasarkan lamanya waktu tempuh staf membawa pasien dari ruang rawat inap menuju 
eksit terdekat di lantai yang sama. Lama ASET dihitung sejak terjadinya penyalaan (ignition) sampai timbulnya untenable condition akibat keracunan atau terpapar asap panas. Variabel yang berpengaruh dan variabel kontrol terhadap lama RSET dan ASET dirumuskan dari beberapa hasil riset yang relevan (Tabel 1).

Tabel 1. Variabel Penelitian

\begin{tabular}{|c|c|c|c|c|}
\hline \multicolumn{3}{|c|}{ Variabel terikat } & Variabel pengaruh & Variabel kontrol \\
\hline \multirow[t]{4}{*}{ RSET } & \multirow[t]{3}{*}{$\begin{array}{l}\text { Waktu Pra- } \\
\text { evakuasi }\end{array}$} & Waktu deteksi & $\begin{array}{l}\text { Tipe alat deteksi } \\
\text { asap }\end{array}$ & $\begin{array}{l}\text { Obyek terbakar } \\
\text { Posisi alat deteksi } \\
\text { Kondisi pintu ruang }\end{array}$ \\
\hline & & $\begin{array}{l}\text { Waktu respon } \\
\text { (pemadaman) }\end{array}$ & $\begin{array}{l}\text { Keterampilan } \\
\text { petugas }\end{array}$ & $\begin{array}{l}\text { Tipe tanda bahaya } \\
\text { Sistem pemadam } \\
\text { Familiarity petugas }\end{array}$ \\
\hline & & $\begin{array}{l}\text { Waktu respon } \\
\text { (persiapan pasien) }\end{array}$ & $\begin{array}{l}\text { Keterampilan } \\
\text { petugas }\end{array}$ & $\begin{array}{l}\text { Kondisi fisik pasien } \\
\text { Rasio petugas dan pasien }\end{array}$ \\
\hline & $\begin{array}{l}\text { Waktu } \\
\text { evakuasi }\end{array}$ & Waktu tempuh & $\begin{array}{l}\text { Jumlah eksit } \\
\text { Jarak tempuh }\end{array}$ & $\begin{array}{l}\text { Kecepatan berjalan } \\
\text { Kepadatan penghuni } \\
\text { Familiarity petugas } \\
\text { Kondisi fisik pasien } \\
\text { Rasio petugas dan pasien }\end{array}$ \\
\hline ASET & Waktu kon & berbahaya & Ventilasi ruang & $\begin{array}{l}\text { Obyek terbakar } \\
\text { Geometri ruang } \\
\text { Sistem pemadam }\end{array}$ \\
\hline
\end{tabular}

\subsection{Metode Pengukuran RSET dan ASET}

Lama Waktu Pra-evakuasi dipengaruhi oleh faktor yang sangat beragam antara lain faktor sosial, fisik bangunan, jenis alat peringatan, dan manajemen sehingga seringkali Waktu Pra-evakuasi sulit diprediksi. Untuk mendistribusi Waktu Pra-evakuasi, Purser D.A (2001) mengusulkan solusi praktis yang dapat digunakan yaitu pengukuran melalui evakuasi terpantau, kejadian kebakaran, atau dengan menggunakan model perilaku. Pada penelitian ini pengukuran RSET dilakukan dengan tiga kombinasi metode, yaitu (1) menggunakan data hasil penelitian sebelumnya, (2) simulasi lapangan, dan (3) simulasi komputer. Metode kedua bertujuan untuk memperoleh besaran waktu tertentu karena besaran waktu yang dimaksud tidak dapat diperoleh baik melalui hasil penelitian sebelumnya maupun dari simulasi komputer. Atau, meskipun tersedia dari hasil penelitian sebelumnya, tetapi tidak dapat langsung digunakan karena adanya perbedaan dengan kondisi aktual yang akan dianalisis. Pengukuran Waktu Pemadaman dan Waktu Persiapan pasien menggunakan metode kedua, sementara pengukuran Waktu Evakuasi dan Waktu Kondisi Berbahaya menggunakan metode ketiga. Pada penelitian ini simulasi lapangan hanya dilakukan pada salah satu rumah sakit yaitu RS1 dengan alasan kemudahan akses dan perijinan, mengingat pelaksanaan simulasi kebakaran di unit rawat inap rumah sakit relatif sulit dan berpotensi mengganggu operasional rumah sakit.

Pengukuran Waktu Deteksi dilakukan dengan menggunakan besaran waktu yang telah tersedia dan dianggap relevan dengan pertanyaan penelitian. Untuk mengukur waktu deteksi studi ini merujuk pada hasil penelitian Notarianni (1993) yang menggunakan perangkat deteksi asap tipe Ionization dan Photoelectric. Kedua alat deteksi tersebut dipasang pada berbagai lokasi di dalam sebuah ruang tidur pasien dengan dua kondisi pintu ruang: terbuka dan tertutup. Obyek terbakar yang digunakan adalah perlengkapan tipikal yang terdapat di dalam sebuah ruang tidur pasien yaitu kasur busa, tempat tidur, dan meja.

Merujuk kepada hasil-hasil studi sebelumnya, dalam penelitian ini dilakukan dua simulasi untuk mengukur Waktu Respon yaitu, simulasi pemadaman api dan simulasi persiapan evakuasi pasien yang dilakukan secara berurutan. Waktu yang diperoleh dari kedua simulasi dijumlahkan menjadi Waktu Respon. Simulasi pemadaman dilakukan 
sesuai dengan kondisi eksisting fisik bangunan dan karakteristik staf rumah sakit obyek studi yaitu, (a) bunyi alarm tidak disertai dengan suara perintah baik dalam bentuk rekaman maupun suara langsung, (b) menggunakan sistem pemadam manual (APAR), dan (c) petugas mengenal dengan baik tanda peringatan bahaya kebakaran. Simulasi persiapan evakuasi pasien menggunakan empat metode evakuasi yaitu menggunakan tempat tidur, kursi roda dengan tabung oksigen, kursi roda tanpa tabung oksigen, dan dipapah oleh petugas. Rasio jumlah petugas dan pasien adalah 2:1. Rasio ini dianggap paling ideal untuk melakukan persiapan pasien baik pada siang maupun malam hari. Besarnya Waktu Respon diambil dari waktu paling lama yang dibutuhkan untuk menyiapkan pasien. Pengukuran lama waktu persiapan dimulai sejak petugas menyiapkan pasien sampai siap dievakuasi menuju ke tempat aman.

Pengukuran Waktu Evakuasi bertujuan untuk mengetahui lama waktu yang dibutuhkan oleh petugas membawa pasien menuju eksit. Kecepatan berjalan petugas dalam membawa atau memindahkan pasien menuju ke tempat aman tergantung dari kondisi beban yang dibawa oleh petugas. Kecepatan berjalan petugas yang digunakan pada penelitian ini mengacu kepada hasil penelitian yang dilakukan oleh (Johnson, 2005) di Glasgow, Inggris yang bertujuan untuk mengetahui pengaruh metode evakuasi dan beban yang dibawa terhadap kecepatan berjalan petugas (Tabel 2). Eksperimen melibatkan perawat sesungguhnya dan sukarelawan yang berperan sebagai pasien, dengan menggunakan tiga alternatif kondisi beban petugas yaitu, (1) tanpa pasien, (2) dengan pasien di atas kursi roda, dan (3) dengan pasien di atas tempat tidur. Selain kondisi beban, digunakan pula dua kondisi kepadatan yang diasumsikan dapat terjadi selama berlangsungnya evakuasi kebakaran, yaitu kondisi padat/berdesakan dan normal.

Tabel 2. Kecepatan Berjalan Petugas Rata-rata

\begin{tabular}{lccc}
\hline $\begin{array}{c}\text { Kondisi eksperimen } \\
\text { (jarak tempuh } 10 \mathrm{~m} \text { ) }\end{array}$ & Lambat & Sedang & Cepat \\
\cline { 2 - 4 } & $\begin{array}{c}\text { Kecepatan } \\
\text { (m/det) }\end{array}$ & $\begin{array}{c}\text { Kecepatan } \\
\text { (m/det) }\end{array}$ & $\begin{array}{c}\text { Kecepatan } \\
\text { (m/det) }\end{array}$ \\
\hline Petugas tanpa pasien & 0.6 & 0.8 & 1.25 \\
Dengan pasien di atas kursi roda & 0.5 & 0.6 & 0.8 \\
Dengan pasien di atas tempat tidur & 0.3 & 0.4 & 0.5 \\
\hline Sumber: Johnson $(2005)$ & & &
\end{tabular}

Sumber: Johnson (2005)

Kepadatan penghuni dihitung berdasarkan jumlah orang dalam satu unit luas area (orang/m2) atau luas area per orang (Pauls, 1988). Pada penelitian ini luas area dihitung berdasarkan luas area yang dibutuhkan oleh seorang petugas membawa pasien menggunakan sebuah tempat tidur, yaitu $=1.0 \mathrm{~m}$ x $2.6 \mathrm{~m}=2.6 \mathrm{~m} 2$. Selanjutnya, dalam pengukuran Waktu Evakuasi, jarak tempuh dihitung dari titik dimulainya evakuasi pada masing-masing ruang tidur pasien ke eksit terdekat yang tersedia. Titik tersebut berada di tengah ruang tidur pasien. Waktu Evakuasi diukur menggunakan simulasi komputer EVACNET4 (Kisko, Francis, and Nobel, 1998) dengan kecepatan berjalan $0.3 \mathrm{~m} /$ detik (Tabel 2). Model jaringan evakuasi kemudian disusun untuk input data EVACNET4 yang menggambarkan ruang-ruang dan jalur-jalur penyelamatan pada setiap lantai dan kapasitas masing-masing jalur tersebut.

Pada bangunan RS1 ruang-ruang pasien berada di lantai 2 sampai lantai 4, karena itu pengukuran Waktu Evakuasi hanya dilakukan berdasarkan kondisi ruang-ruang di lantai-lantai tersebut. Ruang-ruang yang termasuk dalam jalur penyelamatan pada lantai 2 sampai lantai 4 (tipikal) adalah ruang tidur pasien, koridor, dan tangga selatan, tangga timur, balkon, tangga barat, serta koridor menuju ke bangunan Instalasi Bedah Sentral di sebelahnya. Sementara pada RS2 ruang tidur pasien terdapat pada lantai 1 sampai dengan lantai 8. Pengukuran Waktu Evakuasi pada bangunan ini dilakukan berdasarkan 
kondisi lantai 1 dan lantai tipikal (2 sampai 8). Pada lantai 1 evakuasi dimulai dari ruang tidur pasien, lalu koridor, kemudian hall dan lobby, dan berakhir pada empat eksit yaitu lobby Gedung Administrasi, lepas eksit di ujung ramp, serta pintu masuk utama sisi utara dan selatan bangunan. Evakuasi pada lantai 2 sampai lantai 8 berakhir pada dua eksit, yaitu lobby Gedung Administrasi dan ramp di sisi barat.

\section{$2.4 \quad$ Skenario}

Dalam simulasi Waktu Respon maupun Waktu Evakuasi digunakan beberapa skenario yang merepresentasikan kondisi yang paling mungkin terjadi ketika kebakaran berlangsung di bangunan rumah sakit. Skenario diperlukan untuk menggambarkan faktor-faktor penting yang mempengaruhi dampak kebakaran, seperti perlengkapan perlindungan kebakaran, sumber-sumber penyalaan, sifat-sifat bahan bakar dan konfigurasinya, karateristik kebakaran, ventilasi, karakteristik dan lokasi penghuni, dan kondisi struktur pendukung serta peralatan lainnya (SFPE-NFPA, 2007). Skenario simulasi Waktu Respon dimulai dari alarm berbunyi, pemadaman api oleh petugas, persiapan evakuasi pasien, sampai pasien siap dievakuasi. Simulasi dilakukan lebih dari dua kali jika waktu yang diperoleh dari setiap simulasi menunjukkan perbedaan yang cukup besar. Jumlah petugas yang memadamkan api adalah 2 orang sementara jumlah petugas yang menyiapkan pasien adalah 1 atau 2 orang, disesuaikan dengan tingkat kemudahan persiapan evakuasi pasien.

Skenario untuk pengukuran Waktu Evakuasi disusun berdasarkan kondisi terbaik dan kondisi terburuk yang diasumsikan terjadi pada saat terjadi kebakaran. Perbedaan antara kondisi terbaik dan terburuk adalah pada kondisi eksit, yaitu untuk kondisi terbaik semua eksit dapat digunakan, dan untuk kondisi terburuk salah satu eksit tertutup, atau hanya satu eksit yang terbuka/dapat digunakan. Evakuasi dilakukan secara serentak dimulai dari masing-masing ruang tidur pasien menuju eksit terdekat. Susunan skenario simulasi RSET tercantum pada Tabel 3.

Table 3. Skenario Simulasi RSET

\begin{tabular}{|c|c|c|}
\hline Simulasi & Tindakan & Skenario \\
\hline \multirow[t]{2}{*}{$\begin{array}{l}\text { Waktu } \\
\text { Respon }\end{array}$} & Pemadaman api & $\begin{array}{l}\text { Alarm tanda bahaya berbunyi, petugas terdekat merespon dengan } \\
\text { mengambil APAR kemudian berlari menuju ruang terbakar, lalu } \\
\text { memadamkan api ( } 2 \text { orang petugas) }\end{array}$ \\
\hline & Persiapan evakuasi pasien & $\begin{array}{l}\text { Menggunakan tempat tidur dan tabung oksigen ( } 2 \text { orang petugas) } \\
\text { Menggunakan kursi roda dan tabung oksigen ( } 2 \text { orang petugas) } \\
\text { Menggunakan kursi roda dan tabung oksigen ( } 1 \text { orang petugas) } \\
\text { Menggunakan kursi roda tanpa tabung oksigen ( } 1 \text { orang petugas) } \\
\text { Dipapah oleh petugas ( } 1 \text { orang petugas) }\end{array}$ \\
\hline $\begin{array}{l}\text { Waktu } \\
\text { Evakuasi }\end{array}$ & Evakuasi pasien menuju eksit & $\begin{array}{l}\text { Semua eksit dapat digunakan } \\
\text { Salah satu eksit tidak dapat digunakan } \\
\text { Hanya satu eksit yang dapat digunakan }\end{array}$ \\
\hline
\end{tabular}

Analisis ASET bertujuan untuk mengidentifikasi pengaruh bukaan pintu ruangruang pasien yang terletak di sepanjang koridor yang mengelilingi atrium terhadap lama waktu terjadinya kondisi berbahaya. Adanya bukaan seperti pintu ruang yang terbuka akan menjadi sarana bagi penetrasi asap baik dari ruang yang terbakar ke koridor lalu ke atrium maupun sebaliknya. Karena itu selain konstruksi tahan api, ruang pasien juga harus dilengkapi dengan pintu tahan api yang dapat menutup sendiri (self-closing door) atau, jika tidak, maka harus dapat dijamin bahwa pintu senantiasa tertutup melalui cara lain (misalnya, pengawasan yang kontinu). Pengukuran waktu kondisi berbahaya dilakukan dengan menggunakan simulasi komputer CFAST 6.1 (Peacock, Richard D., Jones, Walter W., Reneke, Paul A., Forney, 2005). Ruang terbakar atau ruang asal api adalah ruang yang mengandung paling banyak benda mudah terbakar, yaitu ruang tidur pasien, dengan 
obyek terbakar adalah perabot standar yang biasanya terdapat pada ruang tidur pasien, yaitu kasur busa polyurethane, lemari kayu lapis, kursi lapis busa polyurethane, sofa busa polyurethane, tirai dari bahan serat sintetis dan TV berangka plastik. Geometri ruang sesuai dengan geometri ruang pada bangunan kasus studi, dan sprinkler otomatis tidak tersedia/tidak berfungsi.

Di dalam skenario kebakaran digunakan dua variasi kondisi ventilasi yaitu, (1) pintu ruang asal api terbuka dan sisi-sisi atrium terbuka, (2) pintu ruang asal api terbuka dan sisi-sisi atrium tertutup. Selain itu ada dua posisi ruang asal api yaitu berhadapan langsung dengan atrium, dan tidak berhadapan dengan atrium. Parameter kondisi berbahaya yang digunakan untuk pengukuran ASET adalah apabila ketinggian lapisan asap mencapai $165 \mathrm{~cm}$ dari atas lantai (maksimum tinggi badan rata-rata perawat pria) atau temperatur asap pada ruang-ruang yang dilalui oleh jalur evakuasi mencapai $120{ }^{\circ} \mathrm{C}$ (D. A. Purser and Bensilum, 2001). Untuk mengokohkan hasil simulasi yang telah dilakukan dan memastikan faktor-faktor yang berpengaruh terhadap hasil yang diperoleh dilakukan analisis sensitifitas. Kondisi variabel skenario pengukuran RSET dan ASET diubah hingga RSET menjadi lebih pendek atau ASET bertambah panjang. Iterasi dilakukan sampai kriteria RSET<ASET terpenuhi. Ketidakpastian dapat ditimbulkan oleh perilaku manusia selama terjadinya kebakaran, keterbatasan dalam prosedur kalkulasi, adanya asumsi-asumsi serta keberagaman kondisi aktual variabel yang tidak dimasukkan ke dalam skenario yang dievaluasi (0. Untuk mengatasi ketidakpastian yang terjadi selama proses analisis, digunakan faktor keamanan 2 (dua).

\section{Hasil dan Diskusi}

Dalam penelitian ini alat deteksi yang digunakan untuk mengukur lama Waktu Deteksi adalah jenis Photoelectric, dengan pertimbangan jenis ini paling cocok digunakan untuk tipe kebakaran bangunan rumah sakit. Menurut hasil penelitian Notarianni (1993), waktu deteksi yang dibutuhkan untuk tipe alat deteksi Photoelectric dan posisi alat deteksi asap pada langit-langit dan dekat pintu ruang tidur adalah 569 detik pada kondisi pintu tertutup, dan 445 detik pada kondisi pintu terbuka. Jika berdasarkan skenario terburuk dan dengan asumsi tipe dan posisi alat deteksi asap yang digunakan pada bangunan RS1 dan RS2 adalah sama maka waktu yang dibutuhkan untuk mendeteksi asap pada bangunan rawat inap RS1 dan RS2 adalah 569 detik.

Dari hasil simulasi pengukuran Waktu Respon diketahui bahwa waktu rata-rata tindakan pemadaman yang dibutuhkan oleh petugas adalah 172 detik, dan waktu terpanjang yang dibutuhkan oleh petugas untuk melakukan tindakan persiapan evakuasi pasien adalah 89 detik, yaitu persiapan evakuasi pasien menggunakan kursi roda dan tabung oksigen oleh satu orang petugas (Tabel 4). Dengan demikian Waktu Respon yang diperoleh adalah 172 detik +89 detik = 261 detik. Dengan memasukkan faktor keamanan 2, maka diperoleh Waktu Respon maksimum 522 detik. Total Waktu Pra-evakuasi adalah jumlah Waktu Deteksi + Waktu Respon yaitu 1091 detik atau 18 menit 11 detik.

Tabel 4. Hasil Simulasi Waktu Persiapan Evakuasi Pasien

\begin{tabular}{lccc}
\hline Metode persiapan evakuasi pasien & $\begin{array}{c}\text { Jumlah } \\
\text { petugas }\end{array}$ & $\begin{array}{c}\text { Jumlah } \\
\text { simulasi }\end{array}$ & $\begin{array}{c}\text { Waktu tindakan persiapan } \\
\text { (det) }\end{array}$ \\
\hline Tempat tidur dan tabung oksigen & 2 & 4 & 41 \\
\hline Kursi roda dan tabung oksigen & 2 & 5 & 48 \\
\hline Kursi roda dan tabung oksigen & 1 & 3 & 89 \\
\hline Kursi roda tanpa tabung oksigen & 1 & 2 & 68 \\
\hline Dipapah & 1 & 5 & 85 \\
\hline
\end{tabular}

(Sumber: Hasil Analisis, 2011) 
Dari hasil simulasi komputer diperoleh Waktu Evakuasi pada bangunan RS1 lantai 2, 3 dan 4 adalah $>300$ detik. Hal ini mengindikasikan bahwa tidak semua penghuni berhasil dievakuasi dalam kurun waktu >300 detik (batas waktu evakuasi yang aman). Kondisi ini terjadi apabila hanya satu eksit dari ketiga eksit yang tersedia yang dapat digunakan. Sementara apabila semua eksit dapat digunakan maka diperoleh waktu evakuasi terpendek yaitu 160 detik. Apabila dikalikan dengan faktor keamanan 2, maka Waktu Evakuasi terpanjang pada bangunan RS1 adalah 600 detik dan terpendek 320 detik. Pada bangunan RS2 jumlah eksit yang tersedia pada lantai 1 berbeda dengan lantai 2 sampai 8. Pada lantai 1 tersedia empat buah eksit, sementara pada lantai lainnya hanya tersedia dua buah eksit. Dalam analisis Waktu Evakuasi pada masing-masing lantai 2 s.d. 8 diperoleh waktu > 300 detik yaitu apabila ramp sebagai salah satu eksit tertutup sementara eksit ke Gedung Administrasi yang terletak di sebelah RS2 terbuka. Sementara pada lantai 1 waktu evakuasi >300 detik apabila hanya pintu utama yang terbuka. Waktu evakuasi lebih pendek diperoleh apabila semua eksit dapat digunakan yaitu rata-rata 210 detik pada lantai 2 s.d. 8 dan 140 detik pada lantai 1 . Waktu evakuasi juga lebih pendek meskipun pintu eksit ke Gedung Administrasi tertutup yaitu rata-rata 240 detik. Apabila dikalikan dengan faktor keamanan 2 maka Waktu Evakuasi terpanjang pada bangunan RS2 adalah 600 detik dan terpendek 280 detik (lantai 1) dan 420 detik (lantai 2 s.d. 8). Jika Waktu Evakuasi tersebut dijumlahkan dengan Waktu Respon maka lama RSET pada bangunan RS1 dan RS2 adalah 1691 detik atau 28 menit 18 detik (Tabel 5). Dari simulasi diketahui waktu terpendek yang dibutuhkan oleh lapisan asap untuk menimbulkan kondisi berbahaya pada masing-masing lantai di bangunan RS1 dan RS 2 seperti tercantum pada Tabel 6 .

Tabel 5. RSET pada Bangunan RS1 dan RS2

\begin{tabular}{ccccc}
\hline $\begin{array}{c}\text { Obyek } \\
\text { studi }\end{array}$ & $\begin{array}{c}\text { Waktu } \\
\text { Pra-evakuasi (det) }\end{array}$ & $\begin{array}{c}\text { Waktu Evakuasi } \\
\text { Terpanjang (det) }\end{array}$ & $\begin{array}{c}\text { Waktu Evakuasi } \\
\text { Terpendek (det) }\end{array}$ & $\begin{array}{c}\text { RSET } \\
\text { (det) }\end{array}$ \\
\hline RS1 & 1091 (lantai 2-4) & 600 (lantai 2-4) & 320 (lantai 2-4) & 1691 \\
RS2 & 1091 (lantai 1-8) & 600 (lantai 1-8) & $\begin{array}{c}420 \text { (lantai 2-8) } \\
240 \text { (lantai 1) }\end{array}$ & 1691 \\
\hline
\end{tabular}

(Sumber: Hasil Analisis, 2011)

Tabel 6. ASET pada Bangunan RS1 dan RS2

\begin{tabular}{|c|c|c|c|c|c|c|}
\hline $\begin{array}{l}\text { Lokasi } \\
\text { asap }\end{array}$ & $\begin{array}{c}\text { RS1 } \\
\text { ASET } \\
\text { (det) }\end{array}$ & $\begin{array}{l}\text { Posisi ruang asal api } \\
\text { terhadap atrium }\end{array}$ & $\begin{array}{l}\text { Kondisi } \\
\text { bukaan }\end{array}$ & $\begin{array}{c}\text { RS2 } \\
\text { ASET } \\
\text { (det) }\end{array}$ & $\begin{array}{l}\text { Posisi ruang asal api } \\
\text { terhadap atrium }\end{array}$ & $\begin{array}{l}\text { Kondisi } \\
\text { bukaan }\end{array}$ \\
\hline Lantai 1 & 300 & - & - & 75 & Berhadapan & Pintu terbuka \\
\hline Lantai 2 & 175 & Tidak berhadapan & Pintu terbuka & 65 & Tidak berhadapan & Pintu terbuka \\
\hline Lantai 3 & 165 & Tidak berhadapan & Pintu terbuka & 45 & Tidak berhadapan & Pintu terbuka \\
\hline Lantai 4 & 75 & Tidak berhadapan & Pintu terbuka & 35 & Tidak berhadapan & Pintu terbuka \\
\hline Lantai 5 & - & - & - & 25 & Tidak berhadapan & Pintu terbuka \\
\hline Lantai 6 & - & - & - & 25 & Tidak berhadapan & Pintu terbuka \\
\hline Lantai 7 & - & - & - & 25 & Tidak berhadapan & Pintu terbuká \\
\hline Lantai 8 & - & - & - & 30 & Berhadapan & Pintu terbuka \\
\hline
\end{tabular}

(Sumber: Hasil Analisis, 2011)

Pada bangunan RS1 dan RS2 waktu terpendek yang dibutuhkan oleh asap untuk menimbulkan kondisi berbahaya terjadi pada kondisi pintu ruang asal api terbuka dan posisi ruang tidak berhadapan langsung dengan atrium. Waktu tercapainya kondisi berbahaya pada lantai-lantai di atas lantai ruang asal api lebih pendek dibandingkan dengan lantai di bawahnya dan lantai ruang asal api itu sendiri. Rata-rata waktu tercapainya kondisi berbahaya lebih panjang pada kondisi pintu ruang asal api tertutup. Namun berbeda dengan RS1, waktu terpendek pada bangunan RS2 tercapai baik pada posisi ruang asal api tidak berhadapan langsung maupun berhadapan langsung dengan atrium. 
Dari hasil analisis sensitifitas diketahui bahwa meskipun digunakan skenario dengan waktu evakuasi terpendek, yaitu semua eksit dapat digunakan, kriteria RSET < ASET belum terpenuhi pada kedua bangunan. Upaya yang dilakukan adalah memperpendek jarak tempuh ke eksit dengan menambahkan area penyelamatan sementara (refuge area) yang dilengkapi dengan eksit horisontal pada jalur-jalur evakuasi (Gambar 4). Namun dengan skenario ini pun kriteria RSET<ASET belum terpenuhi. Upaya berikutnya selain penambahan refuge area dan eksit horizontal adalah dengan menutup pintu ruang asal api dan menutup sekeliling atrium dengan penghalang asap. Tindakan menutup pintu ruang pasien adalah selain untuk mencegah masuknya asap ke dalam ruang dan menciptakan kompartemen juga untuk mengurangi jumlah pasien yang harus dipindahkan. Dengan demikian syarat minimum rasio petugas dan pasien dapat terpenuhi dan waktu persiapan pasien menjadi lebih singkat. Hasil analisis menunjukkan bahwa pada kondisi ini kriteria RSET < ASET tercapai pada kedua bangunan kasus studi.

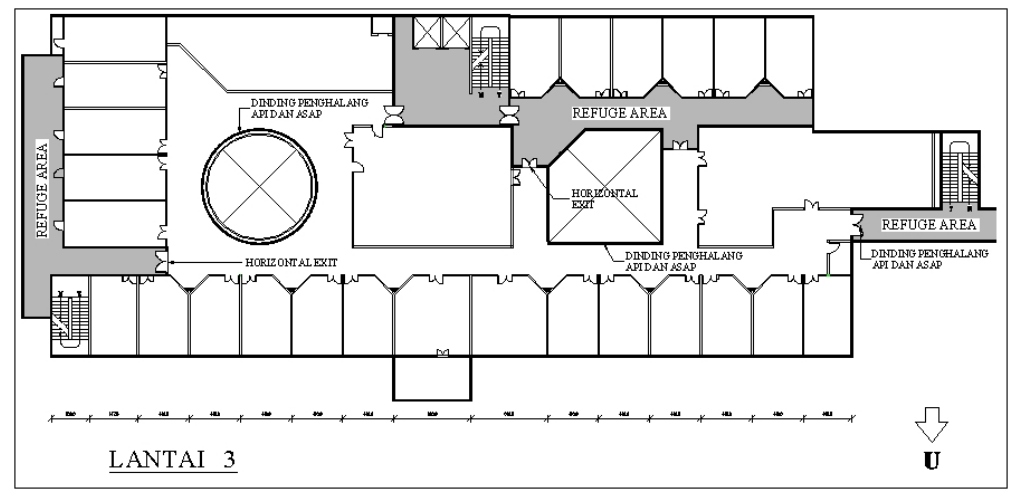

Gambar 4. Penambahan refuge area dan eksit horizontal pada bangunan RS1

\section{Simpulan}

Penggunaan atrium pada bangunan rumah sakit dapat menimbulkan risiko terhadap keselamatan jiwa pasien ketika terjadi kebakaran karena lamanya waktu yang dibutuhkan untuk menyiapkan dan memindahkan pasien ke tempat aman. Atrium terbuka dapat menjadi sarana penyebaran asap dengan sangat cepat sehingga dapat menutupi jalur-jalur evakuasi sebelum proses evakuasi pasien selesai. Padahal atrium dibutuhkan untuk membantu menciptakan suasana yang nyaman untuk mempercepat proses penyembuhan pasien. Kontradiksi penggunaan atrium pada bangunan rumah sakit dapat diatasi dengan cara menutup semua pintu atau bukaan pada ruang yang pertama terbakar pada saat terjadi kebakaran, dan menutup sekeliling atrium dengan penghalang asap untuk mencegah penetrasi asap ke dalam jalur-jalur evakuasi. Upaya tersebut akan menambah waktu yang tersedia untuk penyelamatan pasien.

\section{Daftar Pustaka}

Babrauskas, Vytenis, Joseph M. Fleming, and B. Don Russell. 2010. RSET/ASET, a Flawed Concept for Fire Safety Assessment. Fire and Materials 34 (7): pp 341-355. https://doi.org/https://doi.org/10.1002/fam.1025.

Belles, Donald W. 1986. Health Care Facilities. In Fire Protection Handbook, edited by Arthur E. Cote, 16th ed., 9-16. Quincy, MA: NFPA.

Bryan, John L. 2008. Human Behavior and Fire. In Fire Protection Handbook, edited by Arthur E. Cote, 20th ed., 4-3 - 4-47. Quincy, MA: NFPA.

Butcher, E.G. 1979. Smoke Control in Fire Safety Design. London: E.\& F.N.SPON. 
Cote, Arthur E., and Percy Bugbee. 1988. Principles of Fire Protection. Quincy, MA: NFPA.

Doheim, R. M., Y. G. Yohanis, A. Nadjai, and H. Elkadi. 2014. The Impact of Atrium Shape on Natural Smoke Ventilation. Fire Safety Journal 63: 9-16. https://doi.org/10.1016/j.firesaf.2013.11.005.

F., Liu, and Fu X.Z. 2001. Experimental Studies on Smoke Filling in Atrium Fires. International Journal on Engineering Performance-Based Fire Codes 3 (3): 113-17. https://www.bse.polyu.edu.hk/researchCentre/Fire_Engineering/summary_of_outp ut/journal/IJEPBFC/V3/p.113-117.pdf.

Gritch, Todd, and Bryan Eason. 2016. Atria Systems_ WBDG - Whole Building Design Guide. 2016. https://www.wbdg.org/guides-specifications/building-envelope-designguide/atria-systems.

Gutiérrez-montes, Cándido, and Guillermo Rein. 2009. Smoke and Fire Dynamics in Atria and Large Enclosures: An Overview. Edited by Pp. I. Søgaard and H. Krogh. Nova Science Publishers, Inc. https://repositorio.upct.es/bitstream/handle/10317/8417/sfd.pdf?sequence=3\&is Allowed=y.

Gutiérrez-Montes, Cándido, Enrique Sanmiguel-Rojas, Antonio S. Kaiser, and Antonio Viedma. 2008. Numerical Model and Validation Experiments of Atrium Enclosure Fire in a New Fire Test Facility. Building and Environment 43 (11): 1912-28. https://doi.org/10.1016/j.buildenv.2007.11.010.

Gwynne, S. M.V., and D. L. Boswell. 2009. Pre-Evacuation Data Collected from a Mid-Rise Evacuation Exercise. Journal of Fire Protection Engineering 19 (1): 5-29. https://doi.org/10.1177/1042391508095093.

Harada, Kazunori. 1999. Performance Based Codes and Performance Based Fire Safety Design. Fire Science and Technology. Vol. 19. https://doi.org/10.3210/fst.19.1.

Hunt, Aoife L.E., Edwin R. Galea, Peter J. Lawrence, Ian R. Frost, and Steven M.V. Gwynne. 2020. Simulating Movement Devices Used in Hospital Evacuation. Fire Technology. https://doi.org/10.1007/s10694-020-00971-5.

Iyendo, Timothy Onosahwo, and Alibaba Halil. 2014. Enhancing the Hospital Healing Environment through Art and Day-Lighting for User's Therapeutic Process. International Journal of Arts and Commerce 3 (9): 101-19. https://ijac.org.uk/images/frontImages/gallery/Vol._3_No._9/9._101-119.pdf.

Jeon, Gyu Yeob, Ju Young Kim, Won Hwa Hong, and Godfried Augenbroe. 2011. Evacuation Performance of Individuals in Different Visibility Conditions. Building and Environment 46 (5): 1094-1103. https://doi.org/10.1016/j.buildenv.2010.11.010.

Jin, Tadahisa. 1997. Studies on Human Behavior and Tenability in Fire Smoke, 3-21. https://iafss.org/publications/fss/5/3/view/fss_5-3.pdf.

Johnson, C.W. 2005. Using Computer Simulations to Support A Risk-Based Approach For Hospital Evacuation. Glasgow, UK. http://www.dcs.gla.ac.uk/ johnson/papers/GHES.PDF.

Kisko, T.M., R.L. Francis, and C.R. Nobel. 1998. EVACNET4 USER'S GUIDE. University of Florida. http://tomkisko.com/ise/files/evacnet/EVAC4UG.HTM.

Kobes, Margrethe, Ira Helsloot, Bauke de Vries, and Jos G. Post. 2010. Building Safety and Human Behaviour in Fire: A Literature Review. Fire Safety Journal 45 (1): 1-11. https://doi.org/10.1016/j.firesaf.2009.08.005.

Kuligowski, E. D. 2008. Modeling Human Behavior during Building Fires. Modeling Human Behavior during Building Fires. https://doi.org/10.6028/NIST.TN.1619.

Lathrop, James K. 2008. Concepts of Egress Design. In Fire Protection Handbook, Vol.I, 20t, pp 4-6-4-91. Quincy, MA: NFPA.

Miller, Ian. 2005. Human Behaviour Contributing to Unintentional Residential Fire Deaths 1997-2003. New Zealand Fire Service Commission. 
https://fireandemergency.nz/assets/Documents/Research-and-reports/Report-47Human-Behaviour-Contributing-to-Unintentional-Residential-Fire-Deaths-19972003.pdf.

NFPA. n.d. Reporter's Guide: The Consequences of Fire. https://www.nfpa.org/News-andResearch/Publications-and-media/Press-Room/Reporters-Guide-to-Fire-andNFPA/Consequences-of-fire\#a.

NHS Department of Health. 2013. Firecode - Fire Safety in the NHS Health Technical Memorandum 05-03: Operational Provisions Part M: Guidance on the Fire Safety of Atria in Healthcare Buildings. https://assets.publishing.service.gov.uk/governments/attachment_data/file.

Notarianni, Kathy A. 1993. Measurement of Room Conditions and Response of Sprinklers and Smoke Detectors During a Simulated Two-Bed Hospital Room Fire. Gaithersburg, MD. https://nvlpubs.nist.gov/nistpubs/Legacy/IR/nistir5240.pdf.

O'Connor, Daniel J., Cohn, Bert. 2008. Strategies for Occupant Evacuation During Emergencies. In Fire Protection Handbook, edited by Arthur E. Cote, Volume I, pp 4103 - 4-111. Quincy, MA: NFPA.

Pauls, Jake. 1988. Movement of People. In SFPE Handbook of Fire Protection Engineering, 1st ed. Quincy, MA: SFPE-NFPA.

Peacock, Richard D., Jones, Walter W., Reneke, Paul A., Forney, Glenn P. 2005. CFAST: Consolidated Model of Fire Growth and Smoke Transport (Version 6). User's Guide. NIST. https://nvlpubs.nist.gov/nistpubs/Legacy/SP/nistspecialpublication1041.pdf.

PERMEN PU No.26/PRT/M/2008. 2008. Persyaratan Teknis Sistem Proteksi Kebakaran Pada Bangunan Gedung Dan Lingkungan. Jakarta: DEPARTEMEN PEKERJAAN UMUM DIREKTORAT JENDERAL CIPTA KARYA. http://ciptakarya.pu.go.id/pbl/index.php/preview/46/permen-pu-no-26-tahun2008-tentang-persyaratan-teknis-sistem-proteksi-kebakaran-pada-bangunangedung-dan-lingkungan.

Purser, D. A., and M. Bensilum. 2001. Quantification of Behaviour for Engineering Design Standards and Escape Time Calculations. Safety Science 38 (2): 157-82. https://doi.org/10.1016/S0925-7535(00)00066-7.

Qin, T. X., Y. C. Guo, C. K. Chan, and W. Y. Lin. 2009. Numerical Simulation of the Spread of Smoke in an Atrium under Fire Scenario. Building and Environment 44 (1): 56-65. https://doi.org/10.1016/j.buildenv.2008.01.014.

Rahouti, Anass, Selim Datoussaid, and Ruggiero Lovreglio. 2016. A Sensitivity Analysis of a Hospital Evacuation in Case of Fire: The Impact of the Percentage of People with Reduced Mobility and the Staff to Occupant's Ratio. In Fire and Evacuation Modelling Technical Conference, 1-14. Torremolinos, Spain: Thunderhead Engineering. https://www.thunderheadeng.com/files/com/FEMTC2016/files/d1-05datoussaid/datoussaid-paper.pdf.

SFPE-NFPA. 2007. SFPE Engineering Guide to Performance-Based Fire Protection. Edited by Betsey Henkels. 2nd ed. Quincy, MA: NFPA.

Shi, C. L., W. Z. Lu, W. K. Chow, and R. Huo. 2007. An Investigation on Spill Plume Development and Natural Filling in Large Full-Scale Atrium under Retail Shop Fire. International Journal of Heat and Mass Transfer 50 (3-4): 513-29. https://doi.org/10.1016/j.ijheatmasstransfer.2006.07.020.

USFA-FEMA. 2017. Civilian Fire Fatalities in Residential Buildings (2013 - 2015). Topical Fire Report Series. https://www.usfa.fema.gov/data/statistics.

Xie, Wei, Eric Wai Ming Lee, Yanying Cheng, Meng Shi, Ruifeng Cao, and Yuchun Zhang. 2020. Evacuation Performance of Individuals and Social Groups under Different Visibility Conditions: Experiments and Surveys. International Journal of Disaster Risk Reduction 47 (February): 101527. https://doi.org/10.1016/j.ijdrr.2020.101527. 
Xu, Xiao Yuan, Zhen Hua Wang, Xuan Ya Liu, Chao Ji, Nian Hao Yu, Hong Ya Zhu, Jing Jing Li, and Peng Fei Wang. 2018. Study on Fire Smoke Control in Super-High Building Atrium. Procedia Engineering 211 (2017): 844-52. https://doi.org/10.1016/j.proeng.2017.12.083.

Yung, David. 2008. Principles of Fire Risk Assessment in Buildings. United Kingdom: John Wiley \& Sons, Ltd. 